epidemiologiske og etiologiske aspekter. Viktigheten av sekundærkreft diskuteres også før forfatterne gir en god presentasjon av metoder, med styrker og begrensninger. De forskjellige primærcancerne gjennomgås for seg i egne kapitler med god tabellmessig oversikt over risiko for utvikling av ulike sekundære kreftsykdommer (ratio av observert cancerinsidens hos kreftoverlevere sammenliknet med forventet forekomst i normalpopulasjonen) i forskjellige observasjonsperioder etter primærcanceren. Faktorer som kan forklare økte insidenser diskuteres også kortfattet, med tanke på felles etiologi for primær- og sekundærsykdommen samt livsstils- og behandlingsmessige årsaker. Kreft hos barn omhandles i eget kapittel. Det beskrives som et av de viktigste områdene, både med tanke på lang levetid etter primærcanceren og høye insidenser av enkelte sekundære kreftdiagnoser, noe som gjør dette til et dominerende felt innenfor forskningen. Hvert kapittel avsluttes med litteraturreferanser.

Til slutt er det en oppsummering og et eget kapittel om helseprioriteringer på populasjonsnivå, med oppfølgingsprogrammer og preventive tiltak.

Alt $i$ alt er dette en lettlest tekst som gir god oversikt over sekundærkreft etter ulike primære krefttyper. Tabellene øker lesbarheten, og The prevention of second primary cancers kan også fungere som oppslagsverk. Den er egnet for både allmennleger og dem som jobber innenfor onkologi, kan hende også for studenter.

\section{Laparoskopisk kirurgi - didaktisk og dyrt atlas med dobbel DVD}

Frantzides CT, Carlson MA, red. Atlas of minimally invasive surgery 264 s, tab, ill, 2 DVD. Philadelphia, PA: Saunders Elsevier, 2008. Pris EUR 180 ISBN 978-1-4160-4108-5

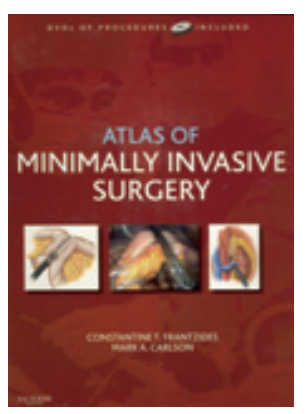

Redaktørene av dette atlaset fremhever at de har gjort et forsøk på å samle de vanligste minimalt invasive prosedyrene som er inkludert i det videre begrepet «generell kirurgi» $i$ én tekst pluss instruksjonsvi-

deoer på to DVD-er. Dette er en «how I do it» hvor de 43 inviterte forfatterne har fått fortelle hvordan de foretrekker å utføre en gitt prosedyre, alt fra laparoskopisk galleoperasjon og appendektomi til laparoskopisk pancreasreseksjon og binyreinngrep. Noen av dem er kjente ressurspersoner innen laparoskopi. Dette er ikke ment å være en vitenskapelig kunnskapsbasert tekst - noe som også fremgår av de ulike kapitlene, som hvert følges av et lite knippe referanser. Det fremgår heller ikke om målgruppen er nybegynnere eller eksperter innen laparoskopi. Man må derfor anta at dette er for den «interesserte», uavhengig av nivå. Enkelte av temaene er likevel utvilsomt best egnet for dem med avansert kunnskap og erfaringsnivå på området.

Kapittelinndelingen er ordnet etter anatomisk område (oesophagus, magesekk, tynntarm, kolorektalområdet, det hepatobiliære, pancreas og milt og nyrer og binyrer) og avsluttes med to om henholdsvis hernier og generelle emner. I sistnevnte beskrives anestesi, bruk av diverse laparoskopisk utstyr og tentative komplikasjoner til laparoskopi - dette kunne med fordel vært det innledende.

Atlaset er rikt illustrert med flotte fargetegninger av særdeles høy kvalitet. Imidlertid kunne man forvente mer trinn-fortrinn-illustrering. Noe av dette bøtes naturlig nok på i de to medfølgende DVDene, der det er redigerte utdrag av samtlige prosedyrer. Enkelte av kapitlene er relativt tynne både på tekst og illustrasjon. For eksempel er kapitlet forfattet av ressurspersonen Antonio Lacy om laparoskopisk lav fremre og abdominoperineal reseksjon kun på fire sider, hvorav det meste av teksten ikke er operasjonstekniske beskrivelser og illustrasjonene er begrenset til pasientleie og trokarplassering.

En del av tilnærmingene er nok ikke representative for hvordan utførelsen er i daglig norsk kirurgi. Eksempelvis demonstreres rutinebruk av Endo-GIA-stifter for avsetting av appendix ved en (relativt blek) appendisitt, mens bruk av endoslynger beskrives som et alternativ i teksten.

Totalt er dette en utgivelse med mange fine bilder og gode illustrasjoner samt interessante videodemonstrasjoner av en rekke laparoskopiske prosedyrer. Prisen (rundt 1800 kroner) trekker imidlertid ned når man har tilgang til gratis demonstrasjonsvideoer av tilsvarende format på lett tilgjengelige nettsteder (f.eks. www.web-

surg.com). For den som har penger til overs og er interessert i laparoskopi, kan den være et nyttig supplement.

\section{Kjetil Søreide}

Kirurgisk avdeling

Stavanger universitetssjukehus

\section{Fullstendig om acetylsalisylsyre}

Schrör K

Acetylsalicylic acid

376 s, tab, ill. Oxford: Wiley-Blackwell, 2008. Pris GBP 45

ISBN 978-3-527-32109-4

Acetylsalisylsyre er et mer enn hundre år gammelt medikament som stadig har fått $ø k t$ anvendelse. Helt frem til de siste tiårene har det fått nye indikasjonsområder. Det er sjelden at ett enkelt medikament blir tema for en egen bok, men acetylsalisylsyre er og forblir en fascinerende substans. Den er beregnet på klinikere, farmakologer og basalforskere. Spennvidden i stoffet er imponerende. Det er bemerkelsesverdig at teksten er skrevet av bare én person, professor Karsten Schrör, som har vært aktiv forsker innen områdene prostaglandinmetabolisme, blodplatefunksjon og koagulasjonssystemet.

Først er det en informativ historikk, videre behandles basalfarmakologi, medikamentsikkerhet og toksikologi, før klinisk anvendelse drøftes. Omtalen av acetylsalisylsyre som behandling både ved tromboemboliske (kardiovaskulære) sykdommer og ved smertetilstander, feber og inflammatoriske sykdommer er oppdatert, og det er en bred redegjørelse for kliniske studier. Mulige nye anvendelsesområder - som forebygging av kolorektal kreft og Alzheimers sykdom - har vært i søkelyset i de senere år, og foreliggende dokumentasjon refereres og drøftes. Litteraturlisten inneholder vel 700 referanser.

Acetylsalicylic acid er oversiktlig, lett å orientere seg i og er utstyrt med velvalgte og informative illustrasjoner.

Man kunne frykte at en så omfattende utgivelse, skrevet av bare en person, kunne få slagside og ikke ha tilstrekkelig kritisk tilnærming til alle områdene som berøres. Dette er ikke tilfellet, den fremstår som balansert, med veloverveide drøftinger.

Den er egnet både som generell lærebok og som referansebok for lesere med ulike interessefelter i forhold til acetylsalisylsyre. Det er lett å søke spesifikk informasjon i aktuelle kapitler, og også lett å supplere opplysningene med stoff fra andre eller fra tilstøtende områder. Eksempelvis kan en som vil innhente klinisk informasjon, også få grei adgang til kunnskap om basalfarmakologiske prinsipper.

Professor Schrör fortjener ros for denne utgivelsen, som er det første komplette oppslagsverket om acetylsalisylsyre. Det er en fornøyelse å lese og slå opp i Acetylsalicylic acid, og mange vil helt sikkert ha glede av å ha den lett tilgjengelig.

\section{Åsmund Reikvam}

Institutt for farmakoterapi

Universitetet i Oslo 